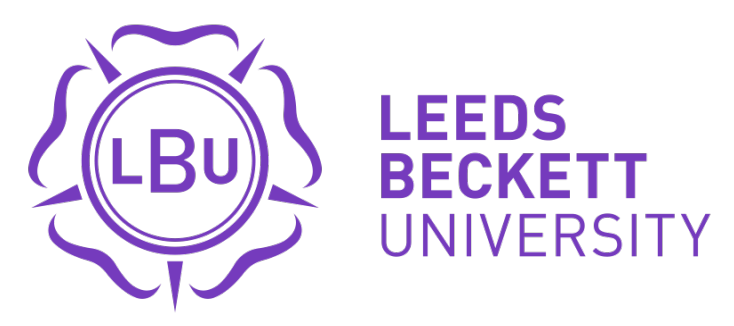

Citation:

Wu, J and Li, H and Lu, Z (2019) Bank diversity and SME innovation: Evidence from China. International Journal of Bank Marketing. ISSN 0265-2323 DOI: https://doi.org/10.1108/IJBM-06-2019-0216

Link to Leeds Beckett Repository record:

https://eprints.leedsbeckett.ac.uk/id/eprint/6220/

Document Version:

Article (Accepted Version)

Creative Commons: Attribution-Noncommercial 4.0

The aim of the Leeds Beckett Repository is to provide open access to our research, as required by funder policies and permitted by publishers and copyright law.

The Leeds Beckett repository holds a wide range of publications, each of which has been checked for copyright and the relevant embargo period has been applied by the Research Services team.

We operate on a standard take-down policy. If you are the author or publisher of an output and you would like it removed from the repository, please contact us and we will investigate on a case-by-case basis.

Each thesis in the repository has been cleared where necessary by the author for third party copyright. If you would like a thesis to be removed from the repository or believe there is an issue with copyright, please contact us on openaccess@leedsbeckett.ac.uk and we will investigate on a case-by-case basis. 


\title{
Bank diversity and SME innovation: Evidence from China
}

Authors - Wu, Junjie; Li, Hongyu; Lu, Zhiqiang

\begin{abstract}
Purpose - This paper examines the relationship between bank diversity and SME firm innovation in China to evaluate the impact of recent bank deregulation.

Design/methodology/approach - Using a large data set that includes 8143 firm-year observations of 1122 listed SME firms in China and baseline and robustness regression analyses, we identify how bank diversity affects firm innovation and via what economic mechanisms. Potential endogeneity problems are considered and addressed in the design and analysis to minimize research bias.
\end{abstract}

Findings - We find robust evidence that bank diversity improves firm innovation. Specifically, the findings suggest that the positive effects of bank diversity on firm innovation are only significant for the firms which are more external finance dependent, have fewer growth opportunities and/or located in the provinces having low financial market development.

Originality/value - This study provides novel evidence and insights into the relationship between banking market structure and the determinants of firm innovation in the Chinese context, as a result of China's banking deregulation.

Keywords: Bank diversity; SME innovation; financing constraints; information asymmetry

Paper type: Research paper 


\section{Introduction}

As bank loans are a vital source of external financing for firms to survive and compete, prior studies on the bank-firm relationship heavily focus on the availability of finance provided by banks and on firms' financial constraints, especially for small and medium-sized enterprises (SMEs; e.g. Ryan et al. 2014). In recent years, rapid development in new technologies has driven more and more firms' innovation ventures, and these innovative firms face more financial constraints by the nature of uncertainty, risk and information opacity associated with innovative projects. As such, a growing literature pays attention to how bank market structure reform and deregulation can help firms' innovation; however, the empirical evidence is not conclusive (Tian et al., 2019). To take some well-cited studies as examples (Chava et al., 2013; Amore et al. 2013; Cornaggia et al., 2015; Berger et al., 2019; Deng et al. 2018), all were conducted in the US, and the results generally favour the notion that improved bank market competition, the resulting increase in credit supply and decrease in finance cost can help enhance firm innovation.

Specifically, relevant studies in the US context concentrate on investigating the impacts of intrastate and interstate banking deregulation between the 1970s and 1990s on economic growth and firms' innovation, and provide either echoed or contrasting empirical evidence from each other. For example, the results from Chava et al. (2013) suggest that intrastate and interstate banking deregulation can play opposite roles in local banks' market power and the level and risk of young and private firms involving in innovation, with the former (intrastate) increasing the local bank market power and decreasing the level and risk of innovation by young and private firms, while the latter (interstate) doing the opposite. They argue that these contrasting impacts of banking deregulation on firm innovation could translate into contrasting influences on economic growth. Amore et al. (2013) examine how staggered interstate banking 
deregulation could benefit manufacturing firms' innovative performance. They find significant benefits in terms of quantity and quality of firms' innovation activities, with performance particularly strong for firms highly dependent on external finance. They also emphasise that the results are largely attributed to geographical banking diversity and a well-functioning financial system. Cornaggia et al. (2015) explore whether the deregulation of interstate bank branching laws affects firm innovation through the changes in bank competition positions. Their findings confirm that bank competition helps small and innovative firms improve financial status and avoid being acquired by large and public firms. Also investigating the impact of staggered interstate bank deregulation, Deng et al. (2018) find bank geographic diversity can boost firms' innovation investments and outputs through testing for causality between bank geographic diversity and firms' innovation. The study of Berger et al. (2019) is conducted from a slightly different perspective. They analyze how bank deregulation influences the growth of financially unconstrained and constrained firms and, in turn, national economic growth. Their results prove that the deregulation is more beneficial to financially unconstrained firms than constrained firms, thus raising concerns for policy improvement. In a very recent paper, Tian et al. (2019) explore the relationship between bank competition and firm innovation efficiencies based on bank structure data between 1992 and 2010 and conclude that increased bank competition can improve firm innovation efficiencies.

The empirical evidence from the above-mentioned studies reveals that the effects of banking market power changes, bank diversity and deregulation on firm innovation can be complex and mixed. One can see that even in the US context, interstate or intrastate deregulation can lead to opposite results (Amore et al., 2013), let alone in other countries which may have disparate bank market structures, financial systems and institutional settings. For instance, the US bank deregulation set up by individual state governments follows a staggered approach which 
includes intrastate deregulation, allowing banks to set up state-wide branches, and interstate deregulation, encouraging mergers and acquisitions (M\&A) across states via bank holding companies (BHCs). The evidence suggests these two types of deregulation produce different economic impacts (Chava et al., 2013; Berger et al., 2019). However, for countries like China, transforming from a socialist centrally planned economy to a socialist market-oriented economic system, the banking deregulation might have a significantly different character to that in the US. To be specific, Chinese banking sector reform develops from a monopolistic state-owned banking system prior to 1978 , then later a state-dominated two-tiered banking system, to nowadays (after banking system reforms from 2003) a market-oriented banking system with diversity in terms of ownership, types, functions, geographical coverage, lending infrastructure and technologies. With regards to the formal banking market, apart from the operation of five state-owned commercial banks (Agricultural Bank of China, Bank of China, China Construction Bank, Industry and Commercial Bank of China, and Bank of Communication ), other types of banks and financial institutions which can currently provide loans to firms include city commercial banks, rural credit cooperatives, rural cooperative banks, rural commercial banks, postal savings banks, village and township banks, loan companies, rural mutual cooperatives, and foreign banks. All of these banks, regardless of ownerships, sizes and geographical locations, are monitored and regulated by the People's Bank of China (PBC) and the former China Banking Regulatory Commission (CBRC, since April 2018 the China Banking and Insurance Regulatory Commission -CBIRC) (Berger et al., 2009) and no M\&A activities are allowed across different ownerships.

It is noted that the literature in relation to bank finance and firm innovation as a result of changes in bank market power, diversity and deregulation is well documented in the US; however, little is known in other contexts, including in China. As discussed, China has had an 
interesting and unique recent history of banking reform and deregulation. This paper therefore aims to fill this gap by examining the relationship between bank diversity and firm innovation, because in China banking deregulation is mainly reflected in the diversity of bank types and the decentralization of the banking market. We focus on innovation in small and medium-sized enterprises (SMEs; to simplify, we use 'firms' hereafter) as they are the most vulnerable and financially constrained group in receiving bank finance due to their smaller size and private ownership (Wu et al., 2018). Guariglia and Liu (2014) investigate to what extent financial constraints affect firm innovation activities using a sample of over 120,000 unlisted Chinese firms over the period 2000-2007, and their findings report that private firms suffer the most from financial constraints on their innovation activities. Arguably, Guariglia and Liu's study does not cover bank deregulation and was conducted in earlier years which might be unable to capture the full influence of bank deregulation on firm innovation. Serious banking reform and deregulation in China only started after CBRC was established in 2003, and the effects of the diversity and deregulation on firm's innovation would be expected to lag.

To achieve our research objective, this paper investigates the impact of bank diversity on firms' innovation outputs using province-level data to measure regional bank diversity. We collect data from firms in the SME Board and the growth enterprise market (GEM) of China covering the period 2007-2017. We find robust evidence that an increase in bank diversity leads to an increase in firms' innovation outputs, supporting by the findings that the firms in the most diversified province ( $95^{\text {th }}$ percentile in the distribution of bank diversity) have a total of $18.5 \%$ more patent applications than the firms in the least diversified province $\left(5^{\text {th }}\right.$ percentile in the distribution). When we use granted patents as a proxy for firm innovation, the result is similar: the firms in the most diversified province $\left(95^{\text {th }}\right.$ percentile in the distribution of bank diversity) have $17.6 \%$ more patents eventually granted than the firms in the least diversified province $\left(5^{\text {th }}\right.$ 
percentile in the distribution).

After confirming a positive relationship between bank diversity and firm innovation, we further examine three possible mechanisms (external finance dependence, firms' growth opportunities and regional financial development) through which bank diversity converts firms' innovation performance. The choice of these three channels, that can be possibly used to explain how and why bank competition, diversity and deregulation influence firm innovation, are supported by the aforementioned studies. With respect to the first channel, external finance dependence is one of the measures in Cornaggia et al. (2015), originally developed by Duchin et al. (2010). We use the same measure to test whether external finance dependence affects the scale of firm innovation outputs by responding to the changes in provincial-level bank diversity first. We presume that bank diversity reduces firm financing constraints mainly for external-financedependent firms. Therefore, these firms should experience an increase in innovation outputs with bank diversity. We find external-finance-dependent firms located in the most diversified provinces (95th percentile in the distribution of bank diversity) have a total of $29.8 \%$ more loan applications and $28.1 \%$ more eventually granted patents than that of the firms in the least diversified province (5th percentile in the distribution). In contrast, we observe no effect of bank diversity on firms with below-median dependence on external finance.

Second, firms' growth opportunities provide another way to test how their needs for credit finance interact with the changes in bank diversity (Ryan et al., 2014). As bank diversity increases, we expect the innovation output of the firms with more growth opportunities to react differently compared to firms with fewer growth opportunities. We expect that high bank diversity would encourage firms borrowing more from banks to invest in innovation because credit availability is high. On the other hand, if a firm showing potential growth, banks might 
value more on the future prosperity of the innovative projects rather than on possible risks associated (Sharpe, 1990). Therefore, the innovation output of firms with more growth opportunities should be less influenced by bank diversity. Interestingly, our test reveals that the impact of bank diversity on innovative outputs is only observed in the firms with fewer growth opportunities and not those with more growth opportunities.

Third, we test the impact of regional financial development on the relationship between bank diversity and firm innovation. It is difficult for firms to finance innovation because of the uncertainty and information asymmetry associated with innovative activities (Acharya and Xu, 2017). However, in a cross-country study with a large data set covering 32 developed and emerging countries, Hsu et al. (2014) find that financial market development should help reduce the problems caused by information asymmetry from innovation activities because wellfunctioning financial markets can effectively reduce financing costs, allocate resources, evaluate projects, manage risk, and even monitor managers. We, therefore, consider that innovative firms in the provinces with a high level of financial market development should be less influenced by bank market structure and diversity as they could get an alternative external finance source. We find the overall positive effects of bank diversity on innovation are particularly strong among firms established in the provinces with a low level of financial market development, proving that firm innovation is weakly affected by bank diversity in the provinces with a high level of financial market development.

The rest of the paper proceeds as follows. Section 2 presents the theoretical background. Section 3 describes the data and variable construction. Sections 4 and 5 present the baseline results and robustness checks respectively. Section 6 tests and discusses the possible mechanisms of our baseline results and Section 7 concludes the study. 


\section{Theoretical background}

Banking market structure determines the competition extent in the market, and strategic choice (Zineldin, 1996). The extant literature has discussed the relationship between banking market structure and firm financial constraints and formed two contrasting theoretical views. On the one hand, market power theory (Klein, 1971) suggests that in a concentrated and less diversified bank market, both competition and market efficiency are low, which can cause banks to supply fewer loans to firms at higher interest rates (Beck et al., 2004; Degryse and Ongena, 2005). As such, bank diversity is conducive to increasing bank competition and became a popular policy in the banking reform and deregulation implemented by governments in different countries, in order to improve the efficiency of the financial system (Berger and Humphrey, 1997) and bank credit availability (Sturm and Williams, 2004). On the other hand, information theory (Petersen and Rajan, 1995) argues that a concentrated market would motivate banks to develop a long-lasting relationship with firms in order to overcome information asymmetry and reduce lending risks, as well as provide knowledge and advice to SMEs (Binks et al., 2006), which implies bank diversity may hinder the establishment of firmbank relationships and increase the financial constraints for firms' innovative projects.

Scholars comment that there are limitations for both the market power and information theories, as both focus on certain aspects while omitting others; some have called for the bank-firm relationship to be evaluated from a broader perspective to reflect a complicated phenomenon (e.g. Beck et al. 2004). We argue that these two theoretical views may contrast at a lower level, i.e. the relationship between banking market structure and firm financial constraints; but, however, they are more compatible at a higher level, i.e. the relationship between banking market structure and firm innovation, intermediated by bank diversity. 
From the market power view, banks with market power are reluctant to provide credit to firms with innovations because innovative projects are normally associated with asymmetric information, high risk for failure and limited collateral value of intangible assets (Hsu et al., 2014; Brown et al., 2017). Therefore, firms have no incentive to undertake innovative projects in a concentrated and less diversified bank market. However, once bank competition increases, banks' behaviour on risk-taking could change accordingly. Compared with a concentrated market structure, banks in the more competitive and diversified market environment are less concerned about risk from innovative projects and are willing to take a high risk to keep their competitive position (Allen and Gale, 2004; Boyd and De Nicolo, 2005). On the other hand, from the information view, relationship-based banking in a concentrated market does not necessarily suggest that innovative firms are more easily financed by banks compared to other non-innovative firms (perhaps the opposite). This is because a concentrated bank market involves fewer banks with monopolistic power and limited expertise in evaluating innovative projects (Scherer, 2011; Atanassov, 2015). Meanwhile, innovative projects may take longer to succeed and require greater tolerance for experimentation and failure (Manso, 2011; Azoulay et al., 2011), and these banks might lack motivations to encourage clients (firms) to take risks on innovative projects as their relationship is already stable (Nakatani, 1984; Rajan and Zingales, 2003). In contrast, in a diversified bank market, there are more lenders from many different backgrounds to evaluate firms' innovative projects, suggesting these innovative projects are more likely to be assessed accurately; conversely, firms have more choices in selecting banks as their innovative project creditors (Allen and Gale, 1999). In addition, a diversified bank system means firms' innovative activities are less likely to be enforced substantial interventions by relationship banking ( $\mathrm{Gu}$ et al., 2017). Finally, different types of banks may adopt different lending technologies and organizational structures (Beck et al., 2011) 
and these lending approaches would be tailored to serve for firm innovative project evaluation. In sum, a diversified banking market structure could encourage firms to pursue innovative projects. We, therefore, expect that bank diversity will positively affect firm innovative outputs.

\section{Data, variable measurement and summary of statistics}

\section{Data}

We compile our data set from several databases. Following Dang and Motohashi (2015) and Fang et al. (2017), we collect patent data from the websites of the Chinese State Intellectual Property Office (CSIPO), and financial statements information from the China Stock Market \& Accounting Research (CSMAR) database. The website of CSIPO provides annual information on the number of patents, the types of patents, a patent's application year, a patent's grant year and patent renewal information. In order to obtain information about various types of financial institutions, we manually collect relevant information from Regional Financial Operation Reports published by the People's Bank of China. Finally, similar to previous research (i.e., Zhou et al., 2017; Fang et al., 2017), we collect macroeconomic information from the China Statistical Yearbook issued by the National Bureau of Statistics of China in order to construct province-level control variables.

In order to achieve our research objective, we choose firms in the SME Board and the GEM instead of the companies listed on the mainboard market of Shanghai and Shenzhen Stock Exchange. The SME Board and the GEM are set up by the Shenzhen Stock Exchange, which is regarded as the "NASDAQ" of China, to encourage SME independent innovation. Most of the firms in these two markets are SMEs with high needs of innovation and financing, and their asset sizes are much smaller than that in the mainboard market. The initial firm sample includes all listed firms in the SME Board and the GEM from 2007 to 2017. We then exclude the firm- 
year observations with missing values. As our study focuses on the analysis of the financing issue in non-financial firms and the comparison of financial information, we exclude financial and utility firms to fit the purpose. In addition, we exclude Tibet province because there are some abnormal and missing values in their macroeconomic and financial institution information. The final sample consists of 8143 firm-year observations from 1122 listed firms.

\section{Measuring innovation}

Following existing literature (e.g. Hsu et al., 2014; Cornaggia et al., 2015; Tian and Han, 2019), we measure corporate innovation by patent-metrics. Based on the information available on the website of CSIPO, we construct two measures for firm-years innovation output. The first measure is the company's number of patent applications (APPLY). Although it is straightforward to compute, this measure cannot identify effective and successful innovative activities. To further assess innovation performance, we construct a second measure of company innovation output by counting a company's number of patents that are eventually granted by CSIPO (GRANT).

In the baseline analysis, our tests are based on firm-year observations. In the later test, as part of robustness checks, we use the total number of patent applications and authorizations in each province and conduct tests at the provincial level. We use the natural logarithm of the total number of patent applications and the natural logarithm of the patents generated (logAPPLY and $\log$ GRANT) as the main innovation measures in our analysis. To avoid losing observations with zero patents, we add one to the actual values when calculating the natural logarithm.

In addition, in the section of robust tests, we redefine APPLY and GRANT as the aggregation of the number of patent applications and grants in our samples at the province-year level, and 
we estimate provincial panel data using fixed-effect panel regression.

\section{Measuring bank diversity and control variables}

The main variable of interest in our analysis is the diversity of bank types. To measure bank diversity, we construct an index based on the asset of different bank types in a given province. For each province-year, we calculate bank diversity through the Herfindahl concentration index for bank assets (DIVERSITY). We calculate the Herfindahl index using type categories of banks in China: state-owned commercial banks, policy bank, joint-stock commercial bank, city commercial bank, rural cooperative financial institution, postal savings bank, new rural financial institution, foreign bank and other. The Herfindahl index is equal to the sum of the squared asset shares of each type of bank. Then, we use 1 minus the Herfindahl index and get the DIVERSITY indicator. We subtract the Herfindahl index because higher values indicate higher bank concentration and lower diversity.

In addition, we recalculate bank diversity via the share of bank assets held by the five largest banks in each province (CR5) in a robust test. All of the five largest banks are state-owned banks with over $40 \%$ of the asset share in most provinces. We calculate bank diversity (DIVERSITY) using 1 minus CR5 in the robust test. We use 1-year lagged bank diversity to analyze the impact on firm innovation.

In our econometric framework, besides the main variables of interest, we need to control for explanatory variables varying with firm, province, and year that affect innovation. Following the innovation literature (see Aghion et al., 2005; Cornaggia et al., 2015; Acharya and Xu, 2017), we include the size of the firm (Log SALES), which is the logarithm of lagged sales. Our specification also includes asset tangibility (PPE), which is the net property plant and 
equipment divided by total assets. We also include a cash holding scale (CASH), which is total cash scaled by total assets. In addition, we control for firm return on assets (ROA), firm leverage (LEV), firm age (AGE) and the proportion of the biggest shareholder (OWN1).

We also control for some macroeconomic variables by referring to Morgan et al. (2004), Benfratello et al. (2008), and Cornaggia et al. (2015). We control for the natural logarithm of provincial GDP per capita (log GDP), total export-import volume divided by GDP (EX-IM), and the degree of government intervention using the proportion of the government's financial expenditure on regional GDP (GOVERN). In addition, we compute the province-level labour force composition for 19 different industry segments following formal industry classification and control for province-level labour force concentration using the the Herfindahl Index (LOBCON). Meanwhile, we also compute the province-level industrial share of total valueadded, and control for province-level industrial concentration using the Herfindahl Index (VALCON).

\section{Summary of statistics}

Table 1 provides summarized statistics of the variables used in this study. As reported in Table 1, at the firm-year level, the average number of patent applications is 39 , of which 28 are granted. Among 142 applications, 105 patents are granted. The mean of log SALES is 20.651 ranging from 19.03 to 22.55 . The mean of ROA is 0.051 ranging between -0.007 and 0.132 . The average of PPE-to-assets and CASH-to-assets ratios are $20 \%$ and $26 \%$ respectively. The range of firm leverage is from 0.309 to 0.671 with a mean of 0.333 . Most firms are more than 12 years old, and the average proportion of shares held by the biggest shareholder is $35 \%$.

At the province-year level, the average value of DIVERSITY is 0.734 . There is a regional 
divergence regarding the level of bank diversity in China, varying from a lower reading 0.654 (with p5) to a higher value of 0.786 (with p95). An average provincial GDP (PGDP) is 54 thousand yuan GDP per capita; the difference between the highest province and the lowest province reaches 75 thousand yuan. The average number of total export-import volume divided by GDP (EX-IM) and the proportion of the government's financial expenditure on regional GDP (GOVERN) is 59\% and 17\% respectively. Lastly, labour force concentration (LOBCON) and industrial concentration value (VALCON) are $18 \%$ and $24 \%$ respectively.

\section{Insert Table 1 here}

Our time series data also show that the year average bank diversity, the yearly average numbers of firm patent applications and grants from 2007 to 2017 steadily grow in the same trend.

\section{The impact of bank diversity on firm innovation}

To assess how banking diversity affects innovation, we estimate the following model:

$\log A P P L Y_{i t}\left(\log G R A N T_{i t}\right)=\alpha+\beta_{1} D I V E R S I T Y_{j t-1}+\gamma Z_{i j t-1}+$ Industy $_{k}+$ Year $_{t}+\varepsilon_{i t}$

where $i$ indexes firm, $t$ indexes time, $j$ indexes province, and $k$ indexes industry. The dependent variables in Eq. (1) are the natural logarithm of the number of patents applied and the natural logarithm of the number of patents granted in a firm. We measure the bank diversity variable (DIVERSITY) for province $j$ in year $t-1 . Z$ is a vector of controls that includes firm-level and province-level variables. Industry $y_{k}$ and Yeart $_{t}$ capture industry and year fixed effects, respectively. 


\section{Insert Table 2 here}

Table 2 presents the results of the baseline estimations. Columns (1) and (3) are estimated using the OLS estimators with sector and year dummies, and the dependent variables are patent applications and patent grants respectively. In relation to the firm-level control variables, the results suggest that larger and high-profit companies display higher innovation, however, high fixed assets and cash ratio, high financial leverage and high equity concentration companies tend to be less innovative. Turning to the province-level control variables, the findings suggest that firm innovation is positively associated with the total export-import volume, labour concentration and industrial concentration, but negatively associated with provincial GDP per capita.

Regarding our variables of interest, the evidence in Table 2 across specifications indicates that bank diversity (DIVERSITY) is negatively associated with innovation. In columns 1 and 3, the coefficient of DIVERSITY is positive $(1.402, t=2.67$ and $1.333, t=2.56)$ and statistically significant at $1 \%$ and $5 \%$ level. The finding supports that bank diversity leads to an increase in the number of firm patents, both in patent applications and patent grants.

The statistically significant coefficients in columns (1) and (3) do not necessarily imply that the observed relationships are also important in economic terms. To assess the economic impact, we move a hypothetical firm from a province at the $5^{\text {th }}$ percentile to a province at the $95^{\text {th }}$ percentile in the distribution of bank diversity and check how this change affects the number of patent grants and patent applications. Based on the coefficient estimate of DIVERSITY in columns (1) and (3), the migration of a firm from the $5^{\text {th }}$ to the $95^{\text {th }}$ percentile in the distribution of bank diversity results in a total of $18.5 \%(=(78.6 \%-65.4 \%) \times 1.402)$ and $17.6 \%\left(=\left(78.6 \% \%^{-}\right.\right.$ 
$65.4 \%) \times 1.333$ ) more patent applications and patent grants. The effect of bank diversity on patent quantity is large: for example, the average number of patent grants in a firm is 58 in 2017 , and the $17.6 \%$ reduction by a drop of 10 patents from the $5^{\text {th }}$ percentile to $95^{\text {th }}$ percentile province in 2017 . This reduction in patent quantity is also significantly relative to the variability of patent grants over time. We make this comparison by taking the average of firm-level patent grants in each of the period from 2007 to 2017 . The standard deviation of these 11 observations is 16 patent grants. Therefore, the comparison shows that the increase in patent quantity as a result of bank diversity increase (from the $5^{\text {th }}$ percentile to $95^{\text {th }}$ percentile province) is equal to $62.5 \%(=10 / 16)$ of the variability of patent production over time. Our findings are in line with the earlier studies (e.g. Chava et al., 2013; Cornaggia et al., 2015) on banking deregulation in the US and suggest that banking deregulation in China also shows a decrease in local market power for banks and an increase in the level of firm innovation.

In Table 2, we consider the potential endogeneity of firm-level variables that may stem from time-invariant confounding factors. To address this, we re-estimate baseline estimations using the fixed effect model. The results in columns (2) and (4) of Table 2 suggest that accounting for firm-level time-unvarying unobservable heterogeneity does not alter the conclusions of our baseline estimate.

\section{Robustness checks}

In this section, we check the robustness of our main findings. We first examine whether our main results are robust to alternative proxies for bank diversity and control variables. Next, we use regional panel data to analyze the impact of regional bank diversity on the total numbers of innovation in provinces. 
Alternative proxies for bank diversity, control variables and innovation

Table 3 re-estimates our baseline estimation using alternative measures of bank diversity, control variables and innovation. First, the measure of bank diversity is replaced by calculating the share of banking system assets held by the five largest banks in each province (CR5) (DIVERSITY $=1-$ CR5), and columns (1) and (2) of Table 3 report the estimation results. Although the coefficient estimation of DIVERSITY in column (1) is not significant, the coefficient is still positive. In the meanwhile, the coefficient in column (2) is negative and significant at the $10 \%$ level, which means the results are basically unaltered.

\section{Insert Table 3 here}

Further, we aggregate the firm-level controls at the province-industry-year level, as it is typically reported in the literature (see Harrison et al., 2014). We thus replace the firm-level variables with the average values for the size, performance, fixed asset ratio, cash ratio, share concentration and age of firms belonging to the same industry, and columns (3) and (4) of Table 3 report the estimation results. In columns (3) and (4), we continue observing positive coefficient estimates of DIVERSITY that are significant at the $5 \%$ level, which means the regression results are unaltered.

\section{Provincial panel data analyses}

In the main analysis, we use firm-level samples to analyze the relationship between bank diversity and firm innovation. In this section, we check whether our main results are robust when we use provincial panel data. To assess how bank diversity affects regional innovation, 
we estimate the following model use province-level samples:

$\log A P P L Y_{j t}\left(\log G R A N T_{j t}\right)=\alpha+\beta_{1} \operatorname{DIVERSITY}_{j t-1}+\gamma Z_{j t-1}+$ Year $_{t}+\varepsilon_{i t}$

where $j$ indexes province and $t$ indexes time. The dependent variables of APPLY and GRANT are the aggregation of the number of patent applications and grants respectively, in our samples at the province-year level. We measure the bank diversity variable, DIVERSITY, using 1-HHI and 1-CR5 for province $j$ in year $t-1 . Z$ is a vector of controls that includes province-level variables. Year ${ }_{t}$ captures year fixed effects. The province-level sample consists of 304 province-year observations representing 30 provinces from 2007 to 2017 . We report the results using provincial panel data in Table 4.

\section{Insert Table 4 here}

In Table 4 , we find that the coefficient estimates of $\beta_{1}$ are all positive and significant for $\operatorname{logAPPLY}$ and $\log$ GRANT at $10 \%$ or $5 \%$ level. The finding supports the conclusion that bank diversity leads to an increase in the total numbers of province patent applications and grants, which is consistent with our baseline analysis.

Overall, the significant effects of bank diversity on innovation remain after altering proxies for bank diversity and control variables, and the level of samples, suggesting that our main findings are robust.

\section{Mechanism tests}

Our evidence so far shows a robust and positive effect of province-level bank diversity on innovation by sample firms. In this section, we explore possible underlying mechanisms 
through which bank diversity may affect firm innovation output. These economic mechanisms are well-embedded in the literature discussed in the introduction. Specifically, we examine whether external finance dependence, growth opportunity, and regional financial development are possible underlying economic mechanisms through which bank diversity affects innovation.

\section{Insert Table 5 here}

\section{External finance dependence}

In this subsection, we examine how bank diversity affects innovation through the first economic mechanism proposed: external finance dependence. The literature agrees that bank diversity is conducive to increasing bank competition and reducing financing constraints for firms' innovation. Compared with other financing channels, firms that are dependent on external finance are more likely to apply for bank credit (Xin et al., 2017). If the banking market structure directly affects the firms' access to credit, their innovation activities would be consequently affected. Therefore, firms that are external-finance-dependent should be affected more by the banking market structure than their counterparts. As such, we expect externalfinance-dependent firms would increase in innovation outputs when bank diversity increases.

Using the measure of external finance dependence developed by Duchin et al. (2010), we construct a variable (External Finance Dependence), which is calculated as (Capital Expenditures - Funds from Operations)/ (Capital Expenditures). We then construct a dummy variable, DEPENDENCE, which equals one for firm-years above the industry median External Finance Dependence value (i.e. more external-finance-dependent) and zero for firm-years below the industry median EXTERNAL FINANCE DEPENDENCE value (i.e. less externalfinance dependent). To examine how firm external finance dependence alters the marginal impact of banking diversity on its innovation, we estimate the following regress model: 
$\log A P P L Y_{i t}\left(\log G R A N T_{i t}\right)$

$$
\begin{aligned}
& =\alpha+\beta_{1} \text { DIVERSITY }_{j t-1}+\beta_{2} \text { DEPENDECE }_{i t-1} \\
& +\beta_{3} \text { DIVERSITY }_{j t-1} \times \text { DEPENDECE } \\
& i t-1 \\
& +\varepsilon_{i t}
\end{aligned}
$$

(3)

where $i$ indexes firm, $t$ indexes time, $j$ indexes province, and $k$ indexes industry. The coefficient on the interaction term, $\beta_{3}$, reflects the different effects of bank diversity on innovation for firms that are more external-finance-dependent. We expect $\beta_{3}$ to be positive and significant.

We report the results estimating Eq. (3) in columns (1) and (2) of Table 5. The coefficient estimates of DIVERSITY are positive but insignificant, suggesting that an increase in bank diversity does not appear to affect innovation for firms that are less dependent on external finance. The coefficient estimates of the interaction term (DIVERSITY $\times$ DEPENDENCE) are positive in both specifications and significant at the $5 \%$ level $(1.597, \mathrm{t}=2.35$ and $1.456, \mathrm{t}=$ 2.16). Based on the coefficient estimate of the interaction term reported in columns (1) and (2), the marginal effect of DIVERSITY for more external-finance-dependent firms are 2.254 $(0.675+1.579)$ and $2.127(0.671+1.456)$, which means more external-finance-dependent firms located in the most concentrated province $\left(95^{\text {th }}\right.$ percentile in the distribution of bank diversity) have a total of $29.8 \%(=(78.6 \%-65.4 \%) \times 2.254)$ more applications and a total of $28.1 \%(=$ $(78.6 \%-65.4 \%) \times 2.127)$ more granted patents than firms in the least concentrated province ( $5^{\text {th }}$ percentile in the distribution of bank diversity). These findings suggest that bank diversity enhances innovation output for more external-finance-dependent firms, leading these firms to apply and be granted more patents, in high bank diversity regions. The result is in line with that in Cornaggia et al. (2015), i.e. innovation with firms that are dependent on external finance 
receive more benefits from banking deregulation.

\section{Growth opportunities}

Next, we examine whether firm growth opportunities interact with the changes in bank diversity to affect their innovation output. We expect that higher bank diversity would encourage firms investing in innovation because firms' innovation projects can be evaluated by different methods of value assessment used by diversified banks. On the other hand, if a firm has more growth opportunities and innovative projects, banks might take it into account when evaluating their innovation projects, i.e. evaluating a whole picture of growth opportunity rather than assessing all individual projects in detail, as banks believe that even if some of the projects do not succeed, other successful projects can offset the loss. As such, lending to innovative firms with more growth opportunities is less likely cause bad debt issues. This hypothesis suggests firm growth opportunity is a substitution mechanism to diversified lending technologies in financing innovation. Therefore, we expect that firms with more growth opportunities should have less increase in innovation output after bank diversity increases.

By referring Cornaggia et al. (2015), we use Tobin's Q as a proxy variable for firm growth opportunities, which is firms' market-to-book ratio and calculated as (market value of equity + book value of assets - book value of equity)/ (book value of assets). And then, we construct a dummy variable, OPPORTUNITY, which equals one for firm-years above the industry median Tobin's Q value (i.e., more growth opportunities) and zero for firm-years below the industry median Tobins Q value (i.e., fewer growth opportunities). To examine how firm growth opportunity alters the marginal impact of bank diversity on its innovation, we estimate the following regress model: 
$\log A P P L Y_{i t}\left(\log\right.$ RANT $\left._{i t}\right)$

$$
\begin{aligned}
& =\alpha+\beta_{1} \text { DIVERSITY }_{j t-1}+\beta_{2} \text { OPPORTUNITY }_{i t-1} \\
& +\beta_{3} \text { DIVERSITY }_{j t-1} \times \text { OPPORTUNITY }_{i t-1}+\gamma Z_{i j t-1}+\text { Industy }_{k}+\text { Year }_{t} \\
& +\varepsilon_{i t}
\end{aligned}
$$

(4)

where $i$ indexes firm, $t$ indexes time, $j$ indexes province, and $k$ indexes industry. The coefficient on the interaction term, $\beta_{3}$ reflects the different effects of bank diversity on innovation for firms with more growth opportunities. We expect $\beta_{3}$ to be negative and significant.

We report the regression results in estimating Eq. (4) in columns (3) and (4) of Table 5. The coefficient estimates of DIVERSITY are positive in both specifications and significant at the $1 \%$ level $(2.065, \mathrm{t}=3.54$ and $1.988, \mathrm{t}=3.43)$, which suggests that bank diversity has a positive effect on innovation output by firms with fewer growth opportunities. The coefficient estimate of the interaction term (DIVERSITY $\times$ OPPORTUNITY) in columns (3) and (4) are negative and significant at the $1 \%$ or $5 \%$ level $(-1.817, \mathrm{t}=-2.61$ and $-1.777, \mathrm{t}=-2.57)$, which means that firms with more growth opportunities are less affected by bank diversity in terms of innovation. Further, the marginal effect of DIVERSITY for firms with more growth opportunities is 0.248 (2.065 - 1.817) and $0.211(1.988-1.777)$, and the joint test of $\beta_{1}+\beta_{3}$ is insignificant $(\mathrm{F}=0.13$ and 0.10). The evidence suggests that although bank diversity positively affects SMEs' innovation in general, this effect mainly comes from the group of firms with fewer growth opportunities. For firms with more growth opportunities, bank diversity does not affect their innovation outputs. Our results parallel those from a large sample of 118,000 SMEs across 20 European countries conducted by Ryan et al. (2014), as their findings conclude that increased market power leads increasing firms' financing constraints, and in turn, decreasing innovation 
outputs.

\section{Regional financial development}

In this subsection, we examine how bank diversity affects innovation through the last economic mechanism proposed: regional financial development. Firms with innovation projects are often in the position of lack of capital as financing innovation tends to be difficult because of the uncertainty and information asymmetry associated (Acharya and $\mathrm{Xu}, 2017$ ). As mentioned earlier, in a diversified banking system, firms' innovative projects can be evaluated by lenders from different backgrounds. This is an important mechanism and an effective way of solving information asymmetry problems. Similarly, one of the important functions of financial market development in a region is to overcome adverse selection and the moral hazard so that the opportunity of firms' access to external capital can be increased (Hsu et al., 2014). In other words, if firms are established in a region with a high level of financial development, it should be easier for them to get external finance to meet their innovation expenditure. That means regional financial development is a substitution mechanism to bank diversity in solving the problem of information asymmetry. Therefore, we expect that firms established in the provinces with a high level of financial development should perform less in innovation output after bank diversity increases.

Using the measure of regional financial development developed by Rajan and Zingales (1998), we construct a variable (Financial Development), which is calculated as (Stock Market Capitalization + Bank Credit)/ (Gross Domestic Product (GDP)). And then, we construct a dummy variable (DEVELOP), which equals one for firms in the province above the median Financial Development value (i.e., high regional financial development) and zero for firms in the province below the median external finance dependence value (i.e., low regional financial 
development). We estimate the following regress model:

$$
\begin{aligned}
\log A P P L Y_{i t}( & \left.\log \operatorname{RANT}_{i t}\right) \\
& =\alpha+\beta_{1} \text { DIVERSITY }_{j t-1}+\beta_{2} \text { DEVELOPMENT }_{i t-1} \\
& +\beta_{3} \text { DIVERSITY }_{j t-1} \times \text { DEVELOPMENT }_{i t-1}+\gamma Z_{i j t-1}+\text { Industy }_{k}+\text { Year }_{t} \\
& +\varepsilon_{i t}
\end{aligned}
$$

Where $i$ indexes firm, $t$ indexes time, $j$ indexes province, and $k$ indexes industry. The coefficient on the interaction term, $\beta_{3}$ reflects the different effects of bank diversity on innovation for firms that in the regions with high financial development. We expect $\beta_{3}$ to be negative and significant.

We report the regression results in estimating Eq. (5) in columns (5) and (6) of Table 5. The coefficient estimates of DIVERSITY are positive in both specifications and significant at the $1 \%$ level $(1.747, t=3.13$ and, $1.619, t=2.93)$, which suggests that bank diversity has a positive effect on innovation outputs for firms in provinces with low financial development. The coefficient estimate of the interaction term (DIVERSITY $\times$ DEVELOPMENT) in columns (5) and (6) are negative and significant at the $5 \%$ level $(-2.317, t=-2.44$ and $-2.627, t=-2.79)$, which means that firms in the provinces with high financial development are less affected by bank diversity on innovation. Further, the marginal effects of DIVERSITY for firms in the provinces with high financial development are -0.57 (1.747- 2.317) and -1.008 (1.619-2.627), and the joint test of $\beta_{1}+\beta_{3}$ are insignificant $(F=0.36$ and 1.13). The evidence suggests that although bank diversity positively affects firms' innovation on average, this effect mainly comes from the group of firms that are established in the provinces with a low level of financial development. For firms that are established in high financial development regions, bank diversity does not affect their innovation outputs significantly. Therefore, this line of our 
evidence echoes the argument proposed by Hsu et al. (2014, p.117) that "equity markets and credit markets could play different roles in determining financing cost and, ultimately, influencing innovation" and their finding that firms being more dependent on external finance and more high-tech intensifying can perform better in countries with better-developed equity markets rather than credit markets.

\section{Concluding remarks}

\section{Contributions and implication}

Motivated by recent Chinese banking market changes from deregulation and more firms engaging in innovation in China, this paper aims to advance our understanding around the relationship between bank diversity and firm innovation as a result of recent bank deregulation from 2003. We have made contributions to the existing body of literature in three ways:

Research about the impacts of bank deregulation on firm innovation is heavily concentrated in the US context, based on intrastate and interstate bank deregulation in the last century, and little has been done in other countries with significantly different banking systems and institutional environments. To the best of our knowledge, this paper has filled a gap by shedding light on the issue of how bank diversity in China affected firm innovation after bank deregulation began in 2003. Despite this, the Chinese banking system has a number of discrepancies with American one which have attracted significant attention in the literature. Our findings have confirmed an observation that firms engaged in more innovation activities in bank diversified regions, which means banking deregulation is conducive to SME innovation in China. The findings support the results in Chava et al. (2013), Amore et al. (2013) and Cornaggia et al. (2015) relating to interstate deregulation. The results prove and confirm that Chinese banking deregulation has achieved a landmark as a catch-up step. From this perspective, our finding should have a 
meaningful policy implication to encourage Chinese banking reform authorities carrying on bank market reform and deregulation, in order for innotative firms to receive more benefits from bank diversity.

From further testing three possible mechanisms (i.e. external finance dependence, firms' growth opportunities and regional financial development) through which bank diversity could convert firms' innovation performance, following the approach used in Duchin et al. (2010), Cornaggia et al. (2015), Ryan et al. (2014), Hsu et al. (2014), and Acharya and Xu (2017), we have found fresh evidence to support these studies in a different country (Chinese context). These findings include: (1) bank diversity plays a more important role for external-financedependent firms than others; (2) a positive impact of bank diversity on innovative outputs has been found for the firms having fewer growth opportunities; (3) the overall positive effects of bank diversity on innovation are particularly strong among firms established in the provinces with a low level of financial market development. Our results highlight that firm characteristics (e.g. external finance dependence and growth opportunities) and financial development are among the factors that affect the relationship between bank diversity and firm innovation. We have discussed the linkage between our findings and those in well-cited studies. These findings suggest that China's central and local governments and banking authorities need to review and assess relevant policies more broadly and in details to tackle the imbalance in relation to firms'financing, growth opportunities and regional financial development.

Although our findings provide support to market power theory, arguing that greater competition decreases the bank market power and alleviate firm financing constraints for innovative projects (Beck et al., 2004), rather than information theory suggesting that bank concentration would be beneficial to building firm-bank relationships and reducing firm financing constraints 
for innovative activities (Hauswald and Marquez, 2006), we have provided an alternative explanation in the theoretical background section to argue that bank diversity is conducive to shaping incentives of firms to pursue innovative projects regardless of whether a market power theory or information theory viewpoint is adopted. However, this could be a future research direction using proper measures to prove it.

\section{Limitations and future research direction}

We recognise that our research is subject to some limitations and the top two relate to sample and measurement. Considering the data availabilities, our sample only includes listed SMEs that are the upper end of this group, therefore caution should be taken when generalising the results to non-listed SME firms. Another limitation is that we can only use patent application and granted numbers as the proxy of firm innovation because we are unable to identify the categories of firm innovative projects. Otherwise, a more interesting analysis could be carried out to find what types of innovation projects attract bank financing. This could be one of the future research directions as well.

\section{Acknowledgement}

The authors appreciate the financial support from the National Social Science Fund of China with Project No: 16CJY073. We are very grateful for the constructive comments provided by the two anonymous reviewers and the high-quality assistance from the editor of International Journal of Bank Marketing, Professor Hooman Estelami. 


\section{References}

Acharya, V. and Xu, Z. (2017), "Financial dependence and innovation: The case of public versus private firms", Journal of Financial Economics, Vol.124 No.2, pp. 223-243.

Aghion, P., Bloom, N., Blundell, R., Griffith, R. and Howitt, P. (2005), "Competition and innovation: An inverted-U relationship", The Quarterly Journal of Economics, Vol. 120 No. 2, pp. 701-728.

Allen, F. and Gale, D. (1999), "Diversity of opinion and financing of new technologies", Journal of Financial Intermediation, Vol. 8 No. 1-2, pp. 68-89.

Allen, F. and Gale, D. (2004), "Competition and Financial Stability", Journal of Money, Credit and Banking, Vol. 36 No. 3, pp. 453-480.

Amore, M., Schneider, C. and Zaldokas, A. (2013), "Credit supply and corporate innovation", Journal of Financial Economics, Vol. 109 No. 3, pp. 835-855.

Atanassov, J. (2015), “Arm's length financing and innovation: Evidence from publicly traded firms", Management Science, Vol. 62 No. 1, pp. 128-155.

Azoulay, P., Graff Zivin, J. S. and Manso, G. (2011), "Incentives and creativity: evidence from the academic life sciences", The RAND Journal of Economics, Vol. 42 No. 3, pp.527-554.

Beck, T., Demirgüç-Kunt, A. and Maksimovic, V. (2004), "Bank competition and access to finance: International evidence", Journal of Money, Credit and Banking, Vol. 36 No. 5, pp. 627-648.

Beck, T., Demirgüç-Kunt, A. and Pería, M. (2011), "Bank financing for SMEs: Evidence across countries and bank ownership types", Journal of Financial Services Research, Vol. 39 No. 12, pp. 35-54.

Benfratello, L., Schiantarelli, F. and Sembenelli, A. (2008), "Banks and innovation: microeconometric evidence on Italian firms", Journal of Financial Economics, Vol. 90 No. 2, pp. 197-217.

Berger, A. N. and Humphrey, D. B. (1997), "Efficiency of financial institutions: International survey and directions for future research", European journal of operational research, Vol. 98 No. 2, pp. 175-212.

Berger, A.N., Hasan, I. and Zhou, M. (2009), "Bank ownership and efficiency in China: What will happen in the world's largest nation?", Journal of Banking \& Finance, Vol. 33 No.1, pp.113-130.

Berger, A.N., Chen, R., Sadok, E. and Omrane, G. (2019), "Who Wins and Who Loses From Bank Geographic Deregulation? Analysis of Financially Constrained and Unconstrained Firms". Available at SSRN 3185751.

Binks, M., Ennew, C. and Mowlah, A. (2006), "The relationship between private businesses and their banks", International Journal of Bank Marketing, Vol. 24 No. 5, pp. 346-355.

Boyd, J.H. and De Nicolo, G. (2005), "The Theory of Bank Risk Taking and Competition Revisited". Journal of Finance, Vol. 60 No. 3, pp. 1329-1343.

Brown, J. R., Martinsson, G. and Petersen, B. C. (2017), "What promotes R\&D? Comparative evidence from around the world", Research Policy, Vol. 46 No 2, pp. 447-462.

Chava, S., Oettl, A., Subramanian, A., and Subramanian, K. V. (2013). "Banking deregulation and innovation", Journal of Financial Economics, Vol. 109 No. 3, pp. 759-774.

Cornaggia, J., Mao, Y., Tian, X. and Wolfe, B. (2015), "Does banking competition affect innovation", Journal of financial economics, Vol. 115 No. 1, pp. 189-209.

Dang, J., and Motohashi, K. (2015), "Patent statistics: A good indicator for innovation in China? Patent subsidy program impacts on patent quality", China Economic Review, Vol. 35 September, pp.137-155.

Degryse, H. and Ongena, S. (2005), "Distance, lending relationships, and competition", The 
Journal of Finance, Vol. 60 No. 1, pp. 231-266.

Deng, S., Mao, C. X., and Xia, C. (2018), "Bank geographic diversification and corporate innovation: Evidence from the lending channel". Available at SSRN 3339576.

Duchin, R., Ozbas, O. and Sensoy, B. (2010), "Costly external finance, corporate investment, and the subprime mortgage credit crisis", Journal of Financial Economics, Vol. 97 No. 3, pp. 418-435.

Fang, L. H., Lerner, J., and Wu, C. (2017). "Intellectual property rights protection, ownership, and innovation: Evidence from China", The Review of Financial Studies, Vol. 30 No. 7, pp. 2446-2477.

Gu, Y., Mao, C. X. and Tian, X. (2017), “Banks' interventions and firms' innovation: Evidence from debt covenant violations", The Journal of Law and Economics, Vol. 60 No. 4, pp. 637671.

Guariglia, A., and Liu, P. (2014), "To what extent do financing constraints affect Chinese firms innovation activities?". International Review of Financial Analysis, Vol. 36 December, 223240.

Harrison, A. E., Lin, J. Y. and Xu, L. C. (2014), "Explaining Africa's (dis)advantage”, World Development, Vol. 63 November, pp. 59-77.

Hauswald, R. and Marquez, R. (2006), "Competition and strategic information acquisition in credit markets", The Review of Financial Studies, Vol. 19 No. 3, pp. 967-1000.

Hsu, P. H., Tian, X. and Xu, Y. (2014), "Financial development and innovation: Cross-country evidence", Journal of Financial Economics, Vol. 112 No. 1, pp. 116-135.

Klein, M. A. (1971), "A theory of the banking firm", Journal of Money, Credit and Banking, Vol. 3 No. 2, pp. 205-218.

Manso, G. (2011), "Motivating innovation", The Journal of Finance, Vol. 66 No. 5, pp. 18231860.

Morgan, D., Rime, B. and Strahan, P. (2004), "Bank integration and state business cycles", Quarterly Journal of Economics, Vol. 119 No. 4, pp. 1855-1885.

Nakatani, I. (1984), "The role of financial corporate grouping". In: Masahiko, A. (Ed.), Economic Analysis of the Japanese Firm, North Holland, New York.

Petersen, M. A. and Rajan, R. G. (1995), "The effect of credit market competition on lending relationships", The Quarterly Journal of Economics, Vol. 110 No. 2, pp. 407-443.

Rajan, R. and Zingales, L. (1998), "Financial development and growth", American Economic Review, Vol. 88 No. 3, pp. 559-586.

Rajan, R. and Zingales, L. (2003), "Banks and markets: the changing character of European finance", The transformation of the European financial system, eds. In V. Gaspar, P. Hartmann, O. Sleijpen. European Central Bank, Frankfurt.

Ryan, R. M., O'Toole, C. M., and McCann, F. (2014), "Does bank market power affect SME financing constraints?" Journal of Banking \& Finance, Vol. 49 December, pp. 495-505.

Scherer, F. M. (2011), "New perspectives on economic growth and technological innovation", Brookings Institution Press.

Sharpe, S. A. (1990), "Asymmetric information, bank lending, and implicit contracts: A stylized model of customer relationships", The Journal of Finance, Vol. 45 No. 4, pp. 10691087.

Sturm, J. E. and Williams, B. (2004), "Foreign bank entry, deregulation and bank efficiency: Lessons from the Australian experience", Journal of Banking and Finance, Vol. 28 No. 7, pp. 1775-1799.

Tian, L. and Han, L. (2019), "How local is local? Evidence from bank competition and corporate innovation in the US", Review of Quantitative Finance and Accounting, Vol. 52 No. 1, pp.1-36. 
Wu, J., Zhu, J., Gold, J. and Fang, H. (2018), “'Hard' lending facilities versus 'soft' banking service - unbalanced bank lending to SMEs in China", International Journal of Business and Globalisation, Vol. 20 No. 3, pp. 328-353.

Xin, F., Zhang, J. and Zheng, W. (2017), "Does credit market impede innovation? Based on the banking structure analysis", International Review of Economics and Finance, Vol. 52 November, pp. 268-288.

Zhou, K. Z., Gao, G. Y., and Zhao, H. (2017), "State ownership and firm innovation in China: An integrated view of institutional and efficiency logics", Administrative Science Quarterly, Vol. 62 No. 2, pp. 375-404.

Zineldin, M. (1996), "Bank strategic positioning and some determinants of bank selection", International Journal of Bank Marketing, Vol. 14 No.6, pp. 12-22. 


\section{Tables}

Table1 Summary of statistics

\begin{tabular}{lrrrrrrr}
\hline Variable & $\mathbf{N}$ & Mean & Median & p5 & p25 & p75 & p95 \\
\hline APPLY & 8143 & 39.246 & 15 & 0 & 4 & 38 & 142 \\
GRANT & 8143 & 28.275 & 10 & 0 & 2 & 28 & 105 \\
Log APPLY & 8143 & 2.589 & 2.773 & 0 & 1.609 & 3.663 & 4.962 \\
Log GRANT & 8143 & 2.290 & 2.398 & 0 & 1.098 & 3.367 & 4.663 \\
DIVERSITY & 8143 & 0.734 & 0.739 & 0.654 & 0.710 & 0.768 & 0.786 \\
log SALES & 8143 & 20.651 & 20.570 & 19.030 & 19.869 & 21.321 & 22.552 \\
ROA & 8143 & 0.051 & 0.050 & -0.007 & 0.025 & 0.076 & 0.132 \\
PPE & 8143 & 0.202 & 0.179 & 0.022 & 0.096 & 0.286 & 0.463 \\
CASH & 8143 & 0.259 & 0.204 & 0.054 & 0.118 & 0.358 & 0.636 \\
LEV & 8143 & 0.333 & 0.309 & 0.068 & 0.178 & 0.467 & 0.671 \\
AGE & 8143 & 12.495 & 12 & 5 & 9 & 15 & 21 \\
OWN1 & 8143 & 0.350 & 0.334 & 0.147 & 0.236 & 0.443 & 0.612 \\
PGDP & 8143 & 10.904 & 10.982 & 10.104 & 10.624 & 11.212 & 11.513 \\
EX\&IM & 8143 & 0.590 & 0.534 & 0.070 & 0.241 & 0.956 & 1.291 \\
GOVERN & 8143 & 0.167 & 0.148 & 0.105 & 0.126 & 0.204 & 0.250 \\
LOBCON & 8143 & 0.180 & 0.198 & 0.076 & 0.126 & 0.221 & 0.286 \\
VALCON & 8143 & 0.239 & 0.237 & 0.194 & 0.227 & 0.256 & 0.277 \\
\hline
\end{tabular}


Table 2 Baseline estimates of the impact of bank diversity on firm innovation

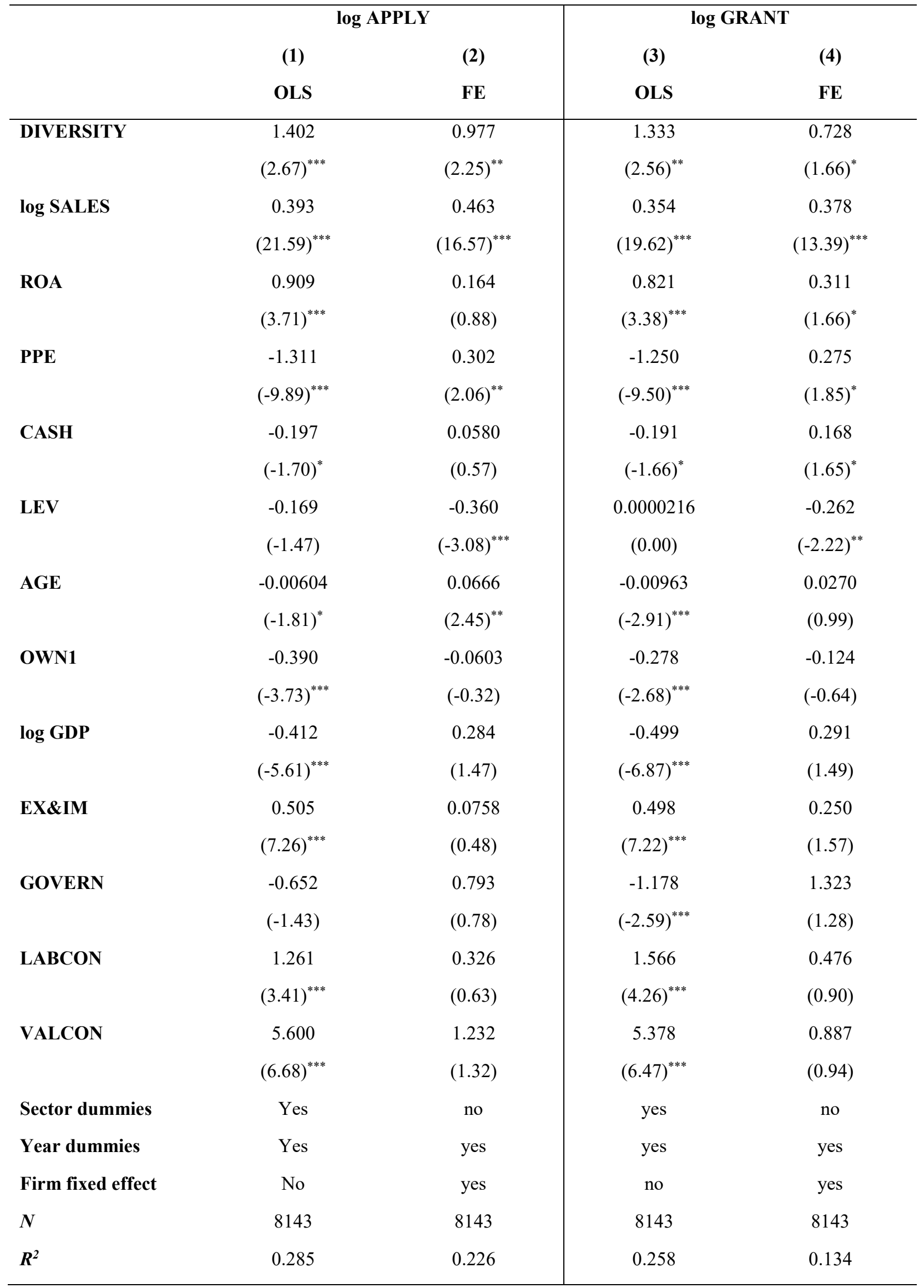

$t$ statistics in parentheses. ${ }^{*} p<0.10,{ }^{* *} p<0.05,{ }^{* * *} p<0.01$ 
Table 3 Robustness check using an alternative measure of variables

\begin{tabular}{|c|c|c|c|c|}
\hline & \multicolumn{2}{|c|}{ DIVERSITY = 1- CR5 } & \multicolumn{2}{|c|}{ Aggregation of firm-level controls } \\
\hline & (1) & (2) & (3) & (4) \\
\hline & $\log A P P L Y$ & Log GRANT & Log APPLY & Log GRANT \\
\hline \multirow[t]{2}{*}{ DIVERSITY } & 0.223 & 0.753 & 1.202 & 1.088 \\
\hline & $(0.55)$ & $(1.85)^{*}$ & $(2.18)^{* *}$ & $(2.00)^{* *}$ \\
\hline \multirow[t]{2}{*}{ In SALES } & 0.393 & 0.355 & 0.230 & 0.203 \\
\hline & $(21.59)^{* * *}$ & $(19.65)^{* * *}$ & $(4.81)^{* * *}$ & $(4.30)^{* * *}$ \\
\hline \multirow[t]{2}{*}{ ROA } & 0.916 & 0.820 & 0.149 & 0.481 \\
\hline & $(3.74)^{* * *}$ & $(3.37)^{* * *}$ & $(0.20)$ & $(0.66)$ \\
\hline \multirow[t]{2}{*}{ PPE } & -1.304 & -1.244 & -0.624 & -0.303 \\
\hline & $(-9.83)^{* * *}$ & $(-9.46)^{* * *}$ & $(-1.95)^{*}$ & $(-0.96)$ \\
\hline \multirow[t]{2}{*}{ CASH } & -0.187 & -0.182 & -0.290 & -0.136 \\
\hline & $(-1.62)$ & $(-1.58)$ & $(-0.94)$ & $(-0.45)$ \\
\hline \multirow[t]{2}{*}{ LEV } & -0.167 & 0.000342 & -0.865 & -0.733 \\
\hline & $(-1.46)$ & $(0.00)$ & $(-2.78)^{* * *}$ & $(-2.39)^{* *}$ \\
\hline \multirow[t]{2}{*}{ AGE } & -0.00575 & -0.00965 & 0.000298 & -0.00316 \\
\hline & $(-1.72)^{*}$ & $(-2.92)^{* * *}$ & $(0.03)$ & $(-0.36)$ \\
\hline \multirow[t]{2}{*}{ OWN1 } & -0.389 & -0.276 & -1.164 & -1.076 \\
\hline & $(-3.72)^{* * *}$ & $(-2.66)^{* * *}$ & $(-4.14)^{* * *}$ & $(-3.88)^{* * *}$ \\
\hline \multirow[t]{2}{*}{$\log$ GDP } & -0.367 & -0.483 & -0.321 & -0.407 \\
\hline & $(-5.03)^{* * *}$ & $(-6.67)^{* * *}$ & $(-4.14)^{* * *}$ & $(-5.33)^{* * *}$ \\
\hline \multirow[t]{2}{*}{ EX\&IM } & 0.447 & 0.478 & 0.465 & 0.457 \\
\hline & $(6.43)^{* * *}$ & $(6.94)^{* * *}$ & $(6.17)^{* * *}$ & $(6.13)^{* * *}$ \\
\hline \multirow[t]{2}{*}{ GOVERN } & -0.603 & -1.188 & -0.0109 & -0.501 \\
\hline & $(-1.31)$ & $(-2.61)^{* * *}$ & $(-0.02)$ & $(-1.05)$ \\
\hline \multirow[t]{2}{*}{ LABCON } & 0.989 & 1.244 & 1.736 & 2.034 \\
\hline & $(2.73)^{* * *}$ & $(3.47)^{* * *}$ & $(4.35)^{* * *}$ & $(5.16)^{* * *}$ \\
\hline \multirow[t]{2}{*}{ GDPCON } & 5.825 & 5.662 & 6.325 & 6.150 \\
\hline & $(6.96)^{* * *}$ & $(6.82)^{* * *}$ & $(7.14)^{* * *}$ & $(7.03)^{* * *}$ \\
\hline Sector dummies & yes & no & yes & no \\
\hline Year dummies & yes & yes & yes & yes \\
\hline$N$ & 8143 & 8143 & 8143 & 8143 \\
\hline$R^{2}$ & 0.284 & 0.258 & 0.221 & 0.199 \\
\hline
\end{tabular}

$t$ statistics in parentheses. ${ }^{*} p<0.10,{ }^{* *} p<0.05,{ }^{* * *} p<0.01$ 
Table 4 Provincial panel data analysis

\begin{tabular}{|c|c|c|c|c|}
\hline & \multicolumn{2}{|c|}{ DIVERSITY = 1- HHI } & \multicolumn{2}{|c|}{ DIVERSITY = 1- CR5 } \\
\hline & (1) & (2) & (3) & (4) \\
\hline & Log APPLY & Log GRANT & Log APPLY & Log GRANT \\
\hline \multirow[t]{2}{*}{ DIVERSITY } & 2.662 & 2.789 & 3.298 & 3.174 \\
\hline & $(1.67)^{*}$ & $(1.73)^{*}$ & $(2.05)^{* *}$ & $(1.94)^{*}$ \\
\hline \multirow[t]{2}{*}{$\log$ GDP } & -1.769 & -1.995 & -1.994 & -2.194 \\
\hline & $(-3.46)^{* * *}$ & $(-3.84)^{* * *}$ & $(-3.70)^{* * *}$ & $(-4.01)^{* * *}$ \\
\hline \multirow[t]{2}{*}{ EX\&IM } & 0.824 & 0.950 & 0.851 & 0.965 \\
\hline & $(1.31)$ & (1.49) & $(1.36)$ & $(1.52)$ \\
\hline \multirow[t]{2}{*}{ GOVERN } & 0.121 & -0.475 & -0.477 & -0.935 \\
\hline & $(0.05)$ & $(-0.19)$ & $(-0.19)$ & $(-0.36)$ \\
\hline \multirow[t]{2}{*}{ LABCON } & -1.563 & -2.106 & -0.276 & -0.811 \\
\hline & $(-0.51)$ & $(-0.68)$ & $(-0.09)$ & $(-0.26)$ \\
\hline \multirow[t]{2}{*}{ GDPCON } & 10.92 & 11.03 & 11.18 & 11.24 \\
\hline & $(4.51)^{* * *}$ & $(4.49)^{* * *}$ & $(4.61)^{* * *}$ & $(4.56)^{* * *}$ \\
\hline $\begin{array}{l}\text { Province } \\
\text { dummies }\end{array}$ & yes & yes & yes & yes \\
\hline Year dummies & yes & yes & yes & yes \\
\hline$N$ & 304 & 304 & 304 & 304 \\
\hline$R^{2}$ & 0.853 & 0.827 & 0.854 & 0.827 \\
\hline
\end{tabular}

$t$ statistics in parentheses, ${ }^{*} p<0.10,{ }^{* *} p<0.05,{ }^{* * *} p<0.01$ 
Table 5 mechanism tests

\begin{tabular}{|c|c|c|c|c|c|c|}
\hline & $\begin{array}{c}\text { (1) } \\
\log A P P L Y\end{array}$ & $\begin{array}{c}(2) \\
\operatorname{logGRAN} \\
T\end{array}$ & $\begin{array}{c}(3) \\
\underset{Y}{\log A P P L} \\
{ }_{Y}\end{array}$ & $\begin{array}{c}(4) \\
\operatorname{logGRAN} \\
T\end{array}$ & $\begin{array}{c}(5) \\
\underset{Y}{\log A P P L} \\
\frac{Y}{1}\end{array}$ & $\begin{array}{c}(6) \\
\operatorname{logGRA} \\
\text { NT }\end{array}$ \\
\hline DIVERSITY & $\begin{array}{l}0.675 \\
(1.12)\end{array}$ & $\begin{array}{l}0.671 \\
(1.12)\end{array}$ & $\begin{array}{c}2.065 \\
(3.54)^{* * *}\end{array}$ & $\begin{array}{c}1.988 \\
(3.43)^{* * *}\end{array}$ & $\begin{array}{c}1.747 \\
(3.13)^{* * *}\end{array}$ & $\begin{array}{c}1.619 \\
(2.93)^{* * *}\end{array}$ \\
\hline DEPENDENCE & $\begin{array}{c}-1.040 \\
(-2.08)^{* * *}\end{array}$ & $\begin{array}{l}-0.953 \\
(-1.92)^{*}\end{array}$ & & & & \\
\hline $\begin{array}{l}\text { DIVERSITY } x \\
\text { DEPENDENCE }\end{array}$ & $\begin{array}{c}1.597 \\
(2.35)^{* *}\end{array}$ & $\begin{array}{c}1.456 \\
(2.16)^{* *}\end{array}$ & & & & \\
\hline OPPORTUNITY & & & $\begin{array}{c}1.332 \\
(2.61)^{* * *}\end{array}$ & $\begin{array}{c}1.279 \\
(2.52)^{* * *}\end{array}$ & & \\
\hline $\begin{array}{l}\text { DIVERSITY } \mathbf{x} \\
\text { OPPORTUNITY }\end{array}$ & & & $\begin{array}{c}-1.817 \\
(-2.61)^{* * *}\end{array}$ & $\begin{array}{c}-1.777 \\
(-2.57)^{* *}\end{array}$ & & \\
\hline DEVELOP & & & & & $\begin{array}{c}1.725 \\
(2.46)^{* *}\end{array}$ & $\begin{array}{c}1.998 \\
(2.87)^{* * *}\end{array}$ \\
\hline $\begin{array}{l}\text { DIVERSITY } x \\
\text { DEVELOP }\end{array}$ & & & & & $\begin{array}{c}-2.317 \\
(-2.44)^{* *}\end{array}$ & $\begin{array}{c}-2.627 \\
(- \\
2.79)^{* * *}\end{array}$ \\
\hline In SALES & $\begin{array}{c}0.399 \\
(21.86)^{* * *}\end{array}$ & $\begin{array}{c}0.359 \\
(19.85)^{* * *}\end{array}$ & $\begin{array}{c}0.391 \\
(20.72)^{* * *}\end{array}$ & $\begin{array}{c}0.349 \\
(18.63)^{* * *}\end{array}$ & $\begin{array}{c}0.392 \\
(21.53)^{* * *}\end{array}$ & $\begin{array}{c}0.353 \\
(19.50)^{* *}\end{array}$ \\
\hline ROA & $\begin{array}{c}0.983 \\
(4.01)^{* * *}\end{array}$ & $\begin{array}{c}0.887 \\
(3.65)^{* * *}\end{array}$ & $\begin{array}{c}0.911 \\
(3.68)^{* * *}\end{array}$ & $\begin{array}{c}0.850 \\
(3.46)^{* * *}\end{array}$ & $\begin{array}{c}0.906 \\
(3.70)^{* * *}\end{array}$ & $\begin{array}{c}0.817 \\
(3.36)^{* * *}\end{array}$ \\
\hline PPE & $\begin{array}{c}-1.261 \\
(-9.46)^{* * *}\end{array}$ & $\begin{array}{c}-1.206 \\
(-9.12)^{* * *}\end{array}$ & $\begin{array}{c}-1.310 \\
(-9.88)^{* * *}\end{array}$ & $\begin{array}{c}-1.251 \\
(-9.51)^{* * *}\end{array}$ & $\begin{array}{c}-1.313 \\
(-9.91)^{* * *}\end{array}$ & $\begin{array}{c}-1.252 \\
(- \\
9.52)^{* * *}\end{array}$ \\
\hline CASH & $\begin{array}{l}-0.173 \\
(-1.49)\end{array}$ & $\begin{array}{l}-0.170 \\
(-1.48)\end{array}$ & $\begin{array}{l}-0.202 \\
(-1.74)^{*}\end{array}$ & $\begin{array}{l}-0.190 \\
(-1.65)^{*}\end{array}$ & $\begin{array}{l}-0.199 \\
(-1.72)^{*}\end{array}$ & $\begin{array}{l}-0.187 \\
(-1.63)\end{array}$ \\
\hline LEV & $\begin{array}{c}-0.208 \\
(-1.81)^{*}\end{array}$ & $\begin{array}{c}-0.0344 \\
(-0.30)\end{array}$ & $\begin{array}{l}-0.169 \\
(-1.47)\end{array}$ & $\begin{array}{c}-0.00370 \\
(-0.03)\end{array}$ & $\begin{array}{l}-0.169 \\
(-1.47)\end{array}$ & $\begin{array}{c}0.00434 \\
(0.04)\end{array}$ \\
\hline AGE & $\begin{array}{c}-0.00561 \\
(-1.69)^{*}\end{array}$ & $\begin{array}{l}-0.00926 \\
(-2.80)^{* * *}\end{array}$ & $\begin{array}{c}-0.00593 \\
(-1.78)^{*}\end{array}$ & $\begin{array}{l}-0.00956 \\
(-2.89)^{* * *}\end{array}$ & $\begin{array}{c}-0.00575 \\
(-1.72)^{*}\end{array}$ & $\begin{array}{c}-0.00930 \\
(- \\
2.81)^{* * *}\end{array}$ \\
\hline OWN1 & $\begin{array}{c}-0.386 \\
(-3.70)^{* * *}\end{array}$ & $\begin{array}{c}-0.275 \\
(-2.65)^{* * *}\end{array}$ & $\begin{array}{c}-0.385 \\
(-3.67)^{* * *}\end{array}$ & $\begin{array}{c}-0.267 \\
(-2.56)^{* *}\end{array}$ & $\begin{array}{c}-0.383 \\
(-3.67)^{* * *}\end{array}$ & $\begin{array}{c}-0.266 \\
(-2.56)^{* *}\end{array}$ \\
\hline
\end{tabular}




\begin{tabular}{|c|c|c|c|c|c|c|}
\hline \multirow[t]{2}{*}{$\log$ GDP } & -0.412 & -0.500 & -0.405 & -0.494 & -0.409 & -0.528 \\
\hline & $(-5.63)^{* * *}$ & $(-6.88)^{* * *}$ & $(-5.53)^{* * *}$ & $(-6.79)^{* * *}$ & $(-5.16)^{* * *}$ & $\begin{array}{c}(- \\
6.71)^{* * *}\end{array}$ \\
\hline \multirow[t]{2}{*}{ EX\&IM } & 0.499 & 0.493 & 0.498 & 0.494 & 0.513 & 0.507 \\
\hline & $(7.19)^{* * *}$ & $(7.15)^{* * *}$ & $(7.15)^{* * *}$ & $(7.15)^{* * *}$ & $(7.38)^{* * *}$ & $(7.35)^{* * *}$ \\
\hline \multirow[t]{2}{*}{ GOVERN } & -0.566 & -1.102 & -0.613 & -1.143 & -0.502 & -1.172 \\
\hline & $(-1.24)$ & $(-2.43)^{* *}$ & $(-1.34)$ & $(-2.52)^{* *}$ & $(-1.02)$ & $(-2.40)^{* *}$ \\
\hline \multirow[t]{2}{*}{ LABCON } & 1.281 & 1.583 & 1.291 & 1.589 & 1.351 & 1.634 \\
\hline & $(3.46)^{* * *}$ & $(4.31)^{* * *}$ & $(3.48)^{* * *}$ & $(4.32)^{* * *}$ & $(3.61)^{* * *}$ & $(4.41)^{* * *}$ \\
\hline \multirow[t]{2}{*}{ GDPCON } & 5.626 & 5.403 & 5.616 & 5.388 & 6.103 & 6.130 \\
\hline & $(6.72)^{* * *}$ & $(6.50)^{* * *}$ & $(6.70)^{* * *}$ & $(6.48)^{* * *}$ & $(6.98)^{* * *}$ & $(7.07)^{* * *}$ \\
\hline Sector dummies & yes & yes & yes & yes & Yes & yes \\
\hline Year dummies & yes & yes & yes & yes & Yes & yes \\
\hline$N$ & 7590 & 7590 & 7759 & 7759 & 8143 & 8143 \\
\hline$R^{2}$ & 0.283 & 0.259 & 0.286 & 0.256 & 0.286 & 0.259 \\
\hline
\end{tabular}

t statistics in parentheses, $* p<0.10, * * p<0.05, * * * p<0.01$ 